\title{
Students' Readiness for the Implementation of E-learning in the College of Basic Education (CBE) in Kuwait during the Covid-19 Pandemic
}

\author{
Dr. Anam AlFadley* \\ Curriculum \& Instruction Department, Public Authority for Applied Education and Training (PAAET) \\ Dr. Amel AlAdwani \\ English Language Department, Public Authority for Applied Education and Training (PAAET) \\ Dr. Maha AlGasab \\ English Language Department, Public Authority for Applied Education and Training (PAAET)
}

\begin{abstract}
The main goal of this research was to investigate the readiness level of student-teachers in CBE in implementing E-learning. This study adopted a survey research design. The readiness of E-learning of the participants was assessed by a 39-item adopted survey. The study sample was 559 female undergraduate fall-time students majoring in teaching English as Foreign language (EFL). The analysis of the results found that the students have high levels of readiness towards E-learning that is due to the training they received online by their college. Additionally, no significant relationship was found between age and the level of readiness of the participants.
\end{abstract}

Keywords: Readiness, E-leaning, Remote-emergency learning, acceptance, and training.

DOI: $10.7176 / \mathrm{JEP} / 12-6-11$

Publication date: February $28^{\text {th }} 2021$

\section{Introduction}

In Spring 2020 the world faced an unpredictable emergency because of the Covid-19 pandemic. The World Health Organization declared that Covid-19 is a global pandemic in March 2020 and warned people about its highly contagious nature (WHO, 2020). Many instructors around the world who normally teach in traditional classes had to pivot overnight to teaching online or use alternative ways to run their classes and help their students ranging from higher education institutes to kindergarten. Other parts of the world stopped teaching while planning how to run their curriculum and wrap up their academic year. Many of these instructors had no previous online teaching experience and many are still confused on how to teach classes online. Therefore, it was important to tackle and document the emergency pivot in education.

In Kuwait, all the higher educational institutes stopped their academic teaching at the beginning of the global Covid-19 pandemic in March and resumed teaching online in August 2020. One of the biggest teaching challenges faced by Kuwait's higher educational institutes was maintaining their teaching when the tools they used for decades in learning suddenly changed to virtual formats. Virtual learning was an approach they felt was hard and uncommon.

Students underwent challenges in learning too. Under Kuwait's partial Lock down policy, that last 7 months, most students felt disconnected from the culture of the classroom learning environment and the collegial relationships. Some students revealed that they felt like they were learning alone, and they noted that they couldn't see how teaching was being modeled anymore. Other students often struggled to put themselves on a schedule and could not engage in a new format of online learning. Therefore, it was important to examine the level of the learners' readiness for E- learning in the College of Basic Education (CBE) which is considered one of the largest educational institutes of The Public Authority of Applied Education and training (PAAET) in Kuwait.

\section{Literature Review}

The technological revolution can not be denied of its huge impact in facilitating work and optimizing performance. Educational institutions, schools, and colleges all around the world are benefitting from the technological revolution by utilizing E-learning. Research suggests that E-learning has become an increasingly popular approach in higher education institutions (Kituyi \& Tusubira, 2013; Tarus, Gichoya, Muumbo, 2015). One reason for the popularity of E-learning in the last 30 years is the advancement of the online technological revolution. This popularity made many prefer distance education over traditional one. Distance education can be traced back to the early 18th century, beginning with the use of parcel post, to radio, to television, and finally to online education which depends basically on the use of computer and Internet (Kentnor, 2015). However, in this critical period of the Covid-19 pandemic, the more accurate term to capture what is being practiced in different 
countries during the interruption of education is what Bozkurt et al. (2020) referred to as Emergency Remote Education (ERE). They explained that distance education is an option that has been developed and grounded in theories and practices while ERE is an obligation that helps education to survive during crisis with all available resources whether offline or online. They also declared "it can be further argued that emergency remote education is a branch of distance education as in the case of online learning, E-learning, M-Learning, or homeschooling" (Bozkurt et al., 2020. P.2). In our study, we will use the term of E-learning as it captured the situation we experienced in our College of Basic Education and it is more specific in its definition as you will read in the next section.

\subsection{What is E-learning}

Recently, the concept of E-learning has been discussed by many researchers and writers under the topics of distance learning, distance education, virtual learning, online learning, web-based learning, blended learning... etc. Many researchers attempted to define E-learning. One of the most comprehensive definition of E-learning comes from the founder of modern E-learning, Badrul H. Khan. Khan (2005) defined E-learning as an innovative approach for delivering well designed, learner centred, interactive, and facilitated learning environments to anyone, any place, anytime by utilizing the attributes and the resources of various digital technologies along with other forms of learning materials suited for the open and distributed learning environment. (P.9)

Others simply defined E-learning as "a learning process which aims to create an interactive learning environment based on the use of computers and the internet" (Mosa, Naz'ri bin, Ibrahim, 2016, P.113). It is clear that all the various definitions of E-learning agree on one main component: the use of computer and internet. According to Tuhaisat and Lansari (2011), "they all define E-learning in terms of technology and agree that E-learning provides a rich integrated environment" (p. 210). For them, E-learning includes a set of basic concepts: learning, technology, and access. Thus, the principle of E-learning is using new multimedia technology and the internet to improve the availability and quality of learning. An E-learning environment could be classified in one of the following two categories: (a) distance education: completely online using, web-based technologies and (b) technology mediated learning: where on-campus teaching is complemented with web-based teaching (Neubauer \& Lober, 2003). In our educational institution, college of education in PAAET, we can be classified as the second category, technology medicated learning. A month into the pandemic, students and instructors in the College of Basic Education have been motivated to adopt the first category, web-based technology as a way of accommodating with the new circumstance. Before this transformation, an important step should occur, measuring the readiness level of students as they are the primary stakeholders in the process of implementing E-learning at PAAET. Due to Kuwaiti government strict protocols such as complete or partial lockdowns and curfews. In June and July, PAEET organized a comprehensive national training campaign for all students and instructors in all higher educational colleges and training institutes. PAAET trained students in using the new educational programs for distance learning that later resume in August 2020.

\subsection{The first step before adopting E-learning/ E-learning Readiness}

Given the preceding background, the main question that this study answers is the level of readiness in utilizing E-learning of our English student-teachers in the CBE. This is because many researchers ensured the importance of being ready for E-learning initiative before starting the journey of adopting it (Akaslan \& Law, 2011a, Moftakhari, 2013, Chapnick, 2005, Morrison, 2003, Mercado, 2008, Tubaishat \& Lansari, 2011, Aldhaferri \& Khan, 2016). Others went further to rely the successfulness of E-learning program upon the learning readiness of three stakeholders of E-learning: teachers, students, and institutions (Oliver, 2001). Lopes (2007) defined Elearning readiness as an institution or individual's ability to benefit from the advantages of online learning, while Kaur and Abas (2004) defined readiness for E-learning as the stakeholders' ability to utilize E-learning resources and multimedia technology with the goal of promoting the quality of learning. Other researchers argued that a readiness assessment is a prerequisite requirement for starting another important of training. For example, DeSimone and Harris (1998) defined readiness assessment as "a process used to better understand the characteristics of the organization to determine where training and human resources development efforts are needed and the conditions within which they will be conducted." (P.27).

An important reason for assessing the readiness level of all stakeholders before adopting E-learning mode in any educational system is what Aldhaferri and Khan (2016) pinpointed at, "an E-learning system involves a systematic process of planning, designing, evaluating, and implementing online learning environments where learning is actively fostered and supported" (P.204). They explained that it needs up-front analysis, development time, money, technological infrastructure, and leadership support. Without assessing the readiness level of all stakeholders, none of the previous steps can be carried out. Many other researchers went further to warn us about implementing E-learning without careful planning since they believe that it may cause massive failure (Tubaihat \& Lansari, 2011, Bean, 2003, Chapnick, 2000, Clark \& Mayer, 2003).

Many models and assessment tools have been established to measure the three stakeholders since only 
through measuring the readiness of each stakeholder, we can determine whether or not we are ready to start the E-learning journey ( Demir \& Yurdugül, 2015 ; Watkins, Leigh, Triner,2004). In this research, we adopted the model of Akaslan and Law (2011). Their model is comprehensive, including three important phases of Elearning and they are: readiness phase, acceptance phase, and training phase (see Figure 1). In the first phase, it is essential to consider four aspects, namely, the people, technology, content, and institution. In the second phase, when the users start to identify the benefits of E-learning, they accept the E-learning process and consider it to be useful. According to Mosa, Naz'ri bin, Ibrrahim (2016), resistance is to be expected from people who are concerned about the implementation of E-learning along with the institution as it inculcates E-learning in its activities. Also, Ford, Ford, and D'Amelio (2008) pinpointed that any change implementation in any field can face some issues and resistance, but eventually it will be accepted. In the third phase, training is given to learners, teachers, facility managers, and other personnel in order to completely adapt to E-learning.

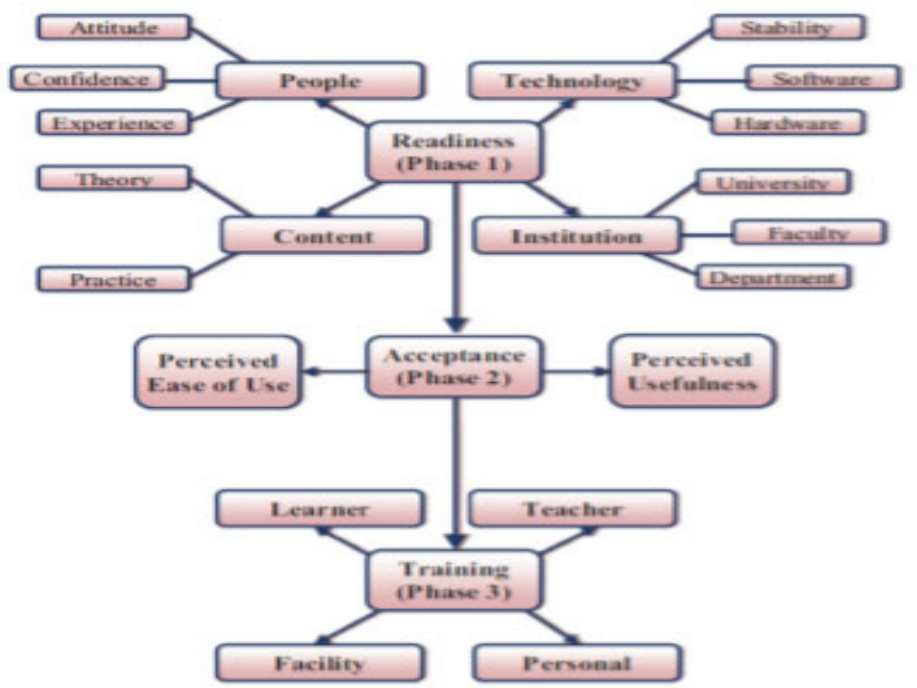

Figure 1: Model for measuring students' readiness for E-learning (Akaslan \& Law, 2011).

\subsection{Why E-learning}

There are many advantages of E-learning as many researchers pinpointed some of these advantages on their studies. The most repeated advantage of E-learning by many researchers is that E-learning can enhance global reach as it is not limited by place or time and has no boundaries between teachers and students as they can interact anytime (Ncube, Dube and Ngulube, 2014, Cooper 2009, De Villiers 2005, Al-juda, 2017). Terminating the limitation of time and space makes E-learning flexible and attractive for learners (Arbaugh \& Duray, 2002). Undoubtedly, this feature had been achieved because of the existence of the internet which makes all of the digital applications possible such as emails, chat rooms, social networks, interactive multimedia applications, web conferences, and internet technologies (Zabadi \&Al-Alawi, 2016). Thus, global communication and internet rapidity are the main features that assist educational institutions in a successful learning and teaching.

Also, Zabadi \&Al-Alawi (2016) pinpointed the advantage of the availability of enriched various educational materials and information that can be obtained and regenerated by students. when students find that content is available and guidance from teachers is introduced whenever is needed in a well-prepared E-learning environment, no doubt s/he will strive to learn. This would lead educators to life-long goal in learning, selfdependent learning. Aldhaferri and Khan (2016) discussed the importance of emphasizing learning-focused or distributed learning environment in which the learner is the center of focus. According to them, E-learning is a good chance for providing that self-dependent environment. They also referred to Banathy (1991, 1992), a leading theorist in educational systems, who recommended learning-centered educational and training system in which the learner is the key entity and he occupies the nucleus of the system. Under the same branch, Payton (2015) also supported the learner-centered approach explaining that the main task of teachers and faculty is making their students empowered by the learning they receive in order to guarantee efficient and effective learning.

Ncube, Dube, and Ngulube (2014) argued that E-learning can create self-directed learning which embodies independence and autonomy through which learners can have full control over their learning. With the same thought, Tubaishat and Lansari (2011) in their study at Zayed University in the UAE found that E-learning helped their participants in building confidence and taking charge of their own learning. Hence confirming that the finding of Tubaishat and Lansari (2011), Appavoo, Soyjaudah, and Armoogum (2015) argued that learners are prepared to take greater control of their own E-learning. This is exactly what our students lack in Kuwait; 
whether in schools or colleges, they do not have self-dependence in learning. In an E-learning educational environment, teachers and students can share information and experiences; they are no longer in traditional classrooms in which only the teacher is the person who provides the students with information. This is because they both find themselves under a highly technological environment where there is no restriction over providing content. All these advantages can motivate students all around the world to get their degrees and overcome all the obstacles that might stop a lot of them from pursuing their study. Therefore, we can agree with Zabadi and Al-Alawi (2016) in that E-learning offered opportunities to encourage education.

\section{4 the age as an independent variable}

Additionally, we are interested in investigating the independent variable of age to find out if younger students would be prepared more than older ones or vice versa. This is evident as Hung, Chou, Chen, Own (2010) and Wojciechowski and Palmer (2005) pinpointed in their research that older students do better in online learning than the younger ones. Xu and Jaggars (2013) found that the effect of age was positive for older students in terms of being adapted more readily to online courses than did young ones, but they did poorly in online courses. However, Appavoo, Soyjaudah, Armoogum (2015) found that young students carried a good perception towards E-learning since more than $70 \%$ students agreed that ICT helps them in providing flexible learning.

\section{Significance of the study}

Many researchers and educators used different types of models and tools to measure the readiness level of students whether in schools or universities in various foreign countries (Akaslan \& Law, 2011, Moftakhari, 2013, Tubaishat \& Lansari, 2011, Ouma, Awuor, Kyambo, 2013, Ünal, Alır, Soydal, 2014). However, the number of studies investigating the readiness level of students for E-learning in the Arabian gulf region, specifically in Kuwait, are few (Al-Juda, 2017; Al-Aldhafeeri \& Khan, 2016). Zabadi and Al-Alawi (2016) emphasized that in general, students in developed countries have positive attitudes towards E-learning. This might be the case as the culture of their communities which motivates technology use in every part of their developing lives. It appears that there are differences among different regions in terms of accepting E-learning. For example, Yuyun's (2013) findings at Krida Wacana Christian University, Jakarta demonstrated that students are significantly ready for online learning and that they significantly show positive attitudes to e-language learning program. However, Rasouli, Rahbania, Attaran (2016) showed moderate level of readiness for applying E-learning in their college student participants in three colleges in Iran. However, in the Arabian Gulf region, specifically Kuwait, most schools and universities have no experience with E-learning. In this case, it might be essential to investigate the level of readiness of our students towards E-learning in Basic College of Education, PAAET.

\section{Methodology}

The current research conducted a quantitative study to examine the mean differences of the students' readiness of 1200 students who are enrolled in the student-teachers undergraduate program in the English department in the College of Basic Education (CBE). The researchers used a self-report survey methodology with several statistical tools to examine mean differences (frequencies \& One-way Anova). The study addressed the following research questions:

Are the students in the English department in the CBE ready for E-learning?

What are the students' self-evaluations about the main components (availability of technology, use of technology, self-confidence, acceptance, and training of E-learning)?

Are there any mean differences among the students' main components based on their age?

\section{Instrument}

The study instrument was adopted from Ünal, Alır, and Soydal (2014) which is a 39-item survey. It is worth noting that their survey was originally developed by Akaslan \& Law (2011) which contains 78 items. The instrument was based on a conceptual model of readiness for E-learning which assessed the perceived readiness in three phases namely, readiness, acceptance, and training measured the students with a binary choice or a fivepoint Likert scale. The readiness scale had five sub-scales to measure aspects of students readiness in:1- selfconfidence (12 items), acceptance of E-learning technology (7 items), availability of technology (6 items), use of technology (11 items), training to E-learning (4 items). The researchers added one item to the training section to include "My institute staff members (library staff, technological support personnel) need training on Elearning". This made the final version of the instrument conclude with 40 items. This is because many researchers emphasized the importance of training institute personnel along with teachers and students. In order to interpret the results, Aydın and Taşçı's (2005) scale for specifying the expected level of readiness was used. The 3.4 indicates where students are ready but need improvement. This scale was also adopted by Akaslan and Law (2011) and Soydal, Alır, Ünal (2011) (See figure 2). 


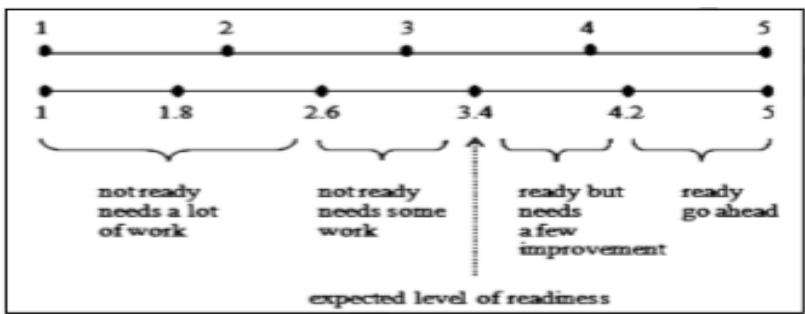

Figure 2: Scale for specifying the expected level of readiness of E-learning

\section{Participants}

The study was carried out during the COVID-19 pandemic period and Kuwait's lockdown period from February to August 2020. The study sample were students in the College of Basic Education which is part of Public Authority for Applied Education and Training (PAAET), one of the highest government educational institutes. The College of Basic Education (CBE) is a 4-year full time teacher training program which includes an English Language department. The participants are mainly female students due to the Kuwait's Ministry of Education (MOE) policy that allows for primary classes to be taught by female teachers only. The participants were randomly selected to answer the survey online via Microsoft Forms through their instructors. The study sample contained 559 undergraduate full-time students majoring in the program designed to graduate teachers to teach English as a foreign language in Kuwait's primary schools. The participants speak English adequately and are taught by instructors in the Curriculum and Instruction Dept and English Language Dept. All their instructors hold PhDs and graduated from British and American universities (AL Darwish, \& Akbar, 2013).

\section{Procedures}

Advance online meetings were conducted with the instructors of each course via Microsoft office Teams, which is the official online E-learning platform during Kuwait's lockdown during the COVID-19 pandemic. The original survey was written in English and distributed. To ensure the validity of this instrument, a panel of professors from the College of Basic Education and Kuwait University reviewed the instruments and endorsed content validity of the items. In addition, the researchers conducted a pilot study prior to the instruments application and modified the questionnaire according to the reviewers and the students' feedback. The E-learning survey questionnaire is scored using the five-points Likert scale. After creating the final form of the questionnaire, the researchers sent the final version of the questionnaire as a web link to be distributed to each class in the English Language department in the College of Basic Education (CBE) at PAAET.

Our findings suggest that the E-learning survey was a reliable instrument in applications with CBE students. The scale has high internal consistency, test-retest reliability, and validity when applied on (CBE) students. A coefficient alpha was calculated to test the internal consistency or reliability of the scale and the sub-scales. The total scale demonstrated excellent reliability with a correlation of 0.92 . While the Alpha for the sub-scales ranged from .875 to .92 .

Table 1. Descriptive Statistics and Reliability Coefficients of the E-learning Readiness survey Scale:

\begin{tabular}{lllll}
\hline Variable & Mean & S.D. & N & Alphas \\
\hline Total Scale & 38.66 & 10.135 & 812 & .92 \\
Sub-Scale Self confidence & 31.94 & 5.65 & 812 & .875 \\
Sub-Scale Acceptance & 28.3 & 5.32 & 812 & .879 \\
Sub-Scale & & & & \\
Sub-Scale & & & & \\
Sub-Scale & & & & \\
\hline
\end{tabular}

\section{Results}

The research questions of this study were answered using several statistical tools. For example, frequencies and One-way Anova were used to answer the three research questions.

4.1 To answer the first research question: Are the students in the English Language Department in the CBE ready for E-learning? The findings of table (3) suggested that there was positive readiness toward implementation of E-learning in the College of Basic Education (CBE) at PAAET. The mean scores ranged from lowest $(M=2.77)$ to highest $(M=4.32)$. The overall mean score of the student's scale was above $(M=3.44)$. Such results revealed that the students are above the average in readiness levels for using E-learning education at the English Language department of CBE. 
Table (3) Mean scores for the E-learning readiness survey

Descriptive Statistics for Overall Items of Readiness Scale for using E-learning

Self Confidence

1: I have information about what is E-learning.

2: I have the skills to operate a computer.

3: I am able to use office software for content delivery and demonstration (PowerPoint

Word, Excel).

4: I am able to use web browsers (e.g: Internet Explorer, Google Chrome).

5: I am able to use search engines (e.g: Google, Yahoo, Bing).

6: I can troubleshoot most problems associated with using a computer

7: I can use digital file management tools (e.g: deleting or renaming a file on your computer).

8: I am able to do my homework by using electronic technology facilities

9: I have enough time to prepare my homework by using electronic technology facilities

10: I am able to use learning management systems (Blackboard, , Teams, Google Classroom Zoom).

11: I believe that E-learning is easy to use.

12: I feel that I am ready for E-learning

Acceptance

13: I am keen to start E-learning

14: I believe that E-learning can enhance the quality of education

15: I believe that using E-learning can increase my productivity

\begin{tabular}{|l|l}
\hline Mean & Std \\
\hline 3.73 & .970 \\
\hline
\end{tabular}

$3.90 \quad 983$

$3.87 \quad 1.016$

$4.27 \quad .913$

$4.29 \quad .796$

$3.22 \quad 1.024$

$3.94 \quad 1.059$

$4.00 \quad .968$

$3.81 \quad 1.028$

$3.68 \quad 1.044$

$3.55 \quad 1.163$

$3.53 \quad 1.245$

16: I believe that E-learning is more effective than the traditional classroom-based approach.

17: I believe that E-learning enables learners and instructors to communicate and interact better with one another.

18: I believe that E-learning has benefits for education

\begin{tabular}{l|l}
\hline 3.55 & 1.170
\end{tabular}

$3.68 \quad 1.107$

$3.70 \quad 1.117$

19: I support implementation of E-learning in my department

\section{Availability of Technology}

20: The hardware facilities are enough.

$2.77 \quad 1.223$

21: The software facilities are enough.

\begin{tabular}{l|l}
3.23 & 1.182
\end{tabular}

$3.55 \quad 1.170$

$3.68 \quad 1.107$

22: The speed of the internet is satisfactory.

23: The stability of the internet access is satisfactory.

24: I have access to computer whenever I need.

25: I can connect to the internet whenever I need.

Usage of Technology

26: I use the internet as an information source

$3.26 \quad .962$

$3.36 \quad .941$

$3.23 \quad 1.115$

$3.29 \quad 1.002$

$3.77 \quad 1.188$

$3.99 \quad 1.105$

27: I use e-mail as the main communication tool with my teachers and classmates.

28: I use office software (e.g: MS. PowerPoint, Word, Excel).

29: I use social network sites (e.g: Facebook, Twitter, Instagram, Twitter Live).

30: I use specific software (e.g: SPSS).

31: I use instant messaging (e.g: Google Talk, Skype).

32: I use Web 2.0 tools (e.g: Blogs, Wiki) to share information.

33: I use file hosting services (e.g: Google Documents, Dropbox).

34: I use learning management systems (Blackboard, Moodle, Teams, Zoom, Google Classroom).

35: I use online forums and chats to communicate with my colleagues.

36: I use smartphone technologies (e.g: Smartphone, Tablet) to connect to the internet.

Training

37: I need training on E-learning.

38: My teachers need training on E-learning.

39: My classmates need training on E-learning.

\begin{tabular}{|l|l}
\hline .99 & 1.105 \\
\hline 4.23 & .741
\end{tabular}

$3.60 \quad 1.136$

$3.87 \quad 1.046$

$4.53 \quad .782$

$3.06 \quad 1.112$

$3.32 \quad 1.197$

$2.97 \quad 1.174$

$3.49 \quad 1.137$

$3.60 \quad 1.158$

$3.75 \quad 1.036$

$4.32 \quad 875$

40: My institute staff members (library staff, technological support personnel) need training on E-learning.

\begin{tabular}{l|l}
\hline .89 & 1.154 \\
\hline & 1.061
\end{tabular}

$3.71 \quad 1.061$

$4.17 \quad 890$

\subsection{To answer the second research question:}

What are the students' self-evaluations about the main components (availability of technology, use of technology, self-confidence, acceptance, and training of E-learning)? Table (3) demonstrated the average means for students' self-evaluation of their readiness level to use the E-learning based upon the scale five components. The results 
showed that the self- confidence mean was $(M=3.81)$, where the most rated item was using search engines in browsing for information $(\mathrm{M}=4.27)$. Meanwhile, the sub-scale acceptance of E-learning was above average $(\mathrm{M}=3.44)$, where the most rated item was their belief that E-learning can increase their productivity $(\mathrm{M}=3.7)$ and enhance the quality of the education $(\mathrm{M}=3.68)$. In addition, the sub-scale of the availability of technology from the student's perception was rated positively as well $(\mathrm{M}=3.48)$, where the most rated item was their availability to connect to the internet whenever they need $(\mathrm{M}=3.99)$. Moreover, the mean score of the student's usage of technology was $(M=3.70)$, where the most rated item was the use of smartphone technologies $(M=4.32)$. Finally, the sub-scale training component was the highest average means for the readiness (3.98), where the most rated item was the needs for more training (4.17) for their classmates and their teachers.

\subsection{To answer the third research question:}

Are there any mean differences among the students' main components based on their age? Table (4) showed the mean differences of the overall scale and its sub-scales based on the students' age. A One-way Anova was used to compare mean scores based upon the student's age on their E-learning readiness. Table (4) showed that there was no significant mean difference based on the total E-learning scale. Although, the age group of 24-29-yearolds showed the highest mean $(\mathrm{M}=98.06)$ compared to other age groups. This mean difference has no statistical significance (F. 2.09, P value of .101). The results were also the case for other the sub-scales. Table (4) showed no statistical mean differences in the 3 sub-scale means based on student's age, self-confidence (F.1.45, P.229), training (F.1.18, P.141), usage of technology (F.1.98, P.116), and availability of technology (F.1.61, P.187). However, only two sub-scales were reported to have low statistical mean significant differences, the acceptance (F.2.67, P .047*), and the readiness subscale (F.1.4, P. .024*).

Table 4. Mean Diferences and Standard Diviation for Age and goup level For The Students' Readiness for $\mathrm{E}$ - learning

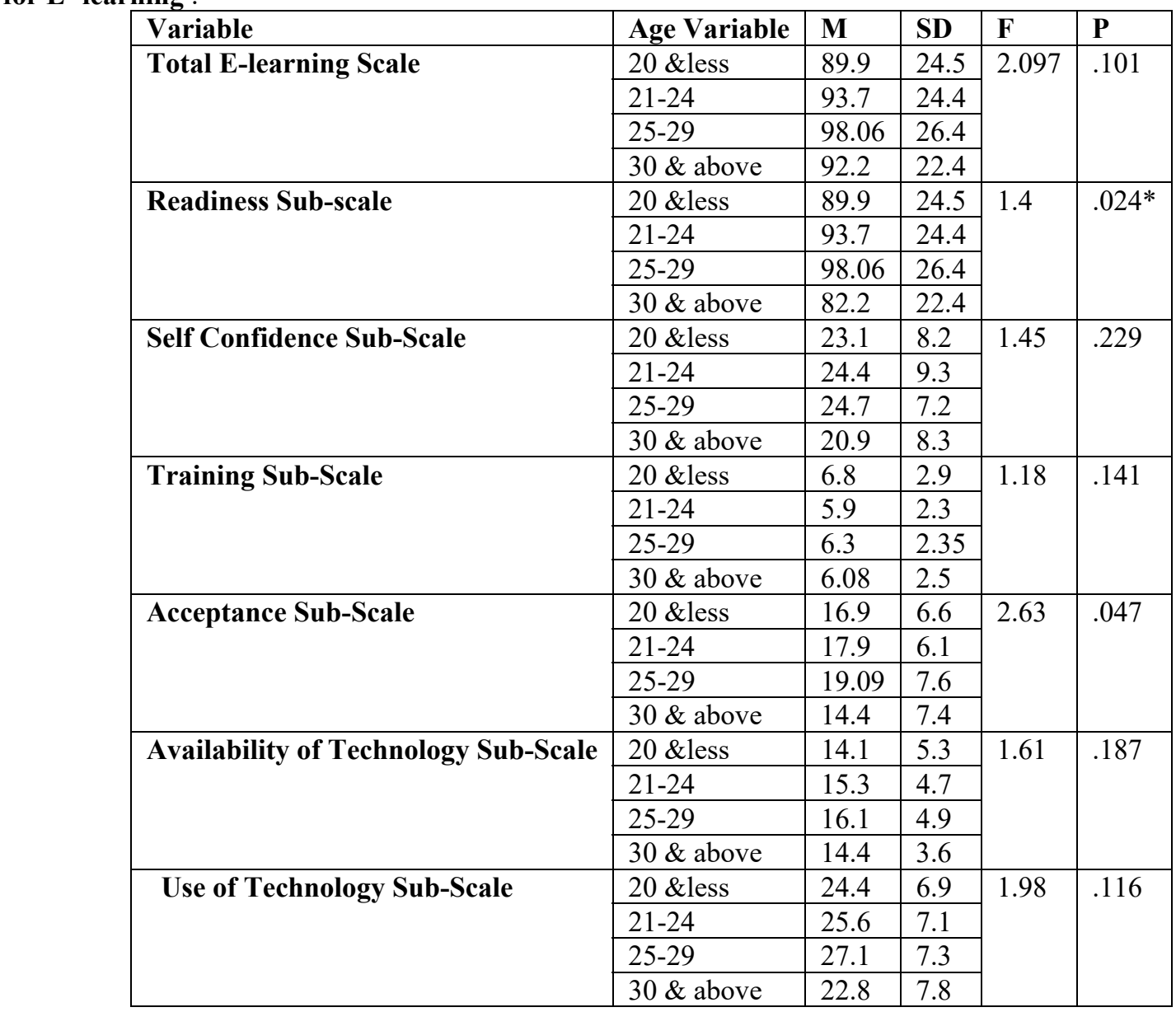

$$
p .05
$$

\section{Discussion}

This study aimed to investigate the readiness level for E-learning of English student-teachers in the College of Education. Specifically, the study explored (1) whether student-teachers are ready for the E-learning implementation process, (2) students' self-evaluation of their own self-confidence, acceptance of technology, 
availability of technology, and training, (3) whether age is a significant variable in determining the level of readiness for E-learning adoption. One of the main findings the study revealed is that CBE student-teachers in the English Language department carry a high level of readiness towards E-learning. This is evidence as the statistical analysis for students' responses suggested that students are above the average of readiness level for using E-learning since the overall mean score of the students 'scale was above $(\mathrm{M}=3.44)$. Therefore, they considered themselves ready to use E-learning. This finding is supported by studies conducted in many different countries that reported positive attitudes towards E-learning (Zabadi \& Alawi, 2016; Appavoo, Soyjaudah, Armoogum, 2015; Al-Aldhafeeri \& Khan, 2016, Yuyun, 2013, Rasouli, Rahbania, Attaran, 2016).

As for the second research question with regards to specifically investigating students' self-evaluation of the five main dimensions related to their readiness towards E-learning, it was found that students considered themselves ready for E-learning (self-confidence mean $=3.81$ ). This is because they felt highly confident in using different search engines and learning management systems (e.g. Teams). Also, students felt ready to experience E-learning due to their beliefs that E-learning can enhance their productivity and enhance the quality of their education. These findings are in agreement with previous studies (e.g. Tubaishat \& Lansari, 2011; Aljuda, 2017; Ncube, Dube and Ngulube, 2014; Appavoo, Soyjaudah, Armoogum, 2015) which highlighted the advantages of using E-learning for students. One main advantage that these studies expressed is that E-learning can teach students independence and autonomy because it advocates self-directed learning. Such learning can revolutionize education and productivity.

In the second dimension, the acceptance level was also high $(\mathrm{M}=3.44)$. Students' responses suggested they considered technology very useful and hence they feel inclined to accept E-learning. It seems that there is a significant relationship between the students' perceived usefulness of E-learning and the level of their acceptance. In other words, when the level of usefulness is high, students' level of acceptance increases. This is in agreement with Aksalan and Law's model (2011) in which they emphasized phase two (acceptance) with two factors: Usefulness of Use and Ease of Use (See figure 1). Another interpretation for such high level of students' acceptance in E-learning implementation is the fact that schools and universities are under complete lockdown during the COVID-19 pandemic. E-learning is the only option for students to continue their studies during the current time. Most students are eager to resume their study by any means and finish their academic courses with E-learning as long as it will keep them safe since it enforces social distancing.

In regards to the third and fourth dimensions, availability of technology from student's perception was rated positively too $(\mathrm{M}=3.48)$. The item that was mostly rated is their availability to connect to the internet. This was expected as Kuwait is a country in which internet is widely available. As for the usage of technology, the mean score of the student's usage of technology was $(M=3.70)$, where the item that was mostly rated was the use of smartphone technology $(M=4.32)$ and other social media platforms $(M=4.53)$. This might be due to the availability and the popularity of smartphone devices more than other technology devices and the excessive use of social media. This result showed that students are digital natives who have grown up with digital technology and who inevitably see the use of technology as part of their life rather than as an add-on (Li, 2017).

When it comes to the readiness level of the last sub-scale, training, it was the highest average mean for readiness among all the other four dimensions (3.98). The item that was mostly rated is the need for more training for their classmates. The researchers believe that the training may be the most essential phase that helped students feel ready and thus accept E-learning faster. In Akaslan and Law's model (2011), the training phase is the third phase after readiness and acceptance. Such model can only be adopted when time is available. However, in Kuwait, because of the COVID-19 pandemic emergency, there was not enough time to survey the readiness and acceptance of the students since the decision for launching the training sessions for students and instructors started spontaneously in June 2020. We collected our data after three weeks of training, a thing we believe had a positive effect on their readiness and acceptance. In other words, we believe that Akaslan and Law's model can have alternative version in which training is the first phase while the readiness and acceptance are the second and third phases, in respect. The new version can suit emergency situations where time is not enough to measure readiness and acceptance of participants before training them.

Another interesting finding that contradicts previous studies which identified age as a significant factor (e.g. Hung, Chou, Own, 2010; Xu \& Jaggars, 2013). The result of our one-way Anova test showed that there were no significant mean differences in the level of readiness of E-learning between age groups. This result can be attributed to the period of time in which this study was conducted (i.e. Covid-19). It is due to the current circumstances that students from all age group are now accepting E-learning as an alternative reliable method of continuing the process of learning.

\section{Conclusion}

Covid-19 made the 2019-2020 academic year one to never forget. With no preparation, schools, teachers, and college instructors were forced to pivot to online teaching globally. In February, the first cases of COVID-19 hit Kuwait. As a result, education changed dramatically, schools and colleges closed, and Kuwait entered lockdown. 
The leader of PAAET colleges and institutes tried to figure out how to complete the academic year, issue grades, and hold graduation ceremonies.

To get out of this mess, the first step that PAAET decided is to launch a large training campaign in June 2020 to resume their academic year by E-learning platforms such as Teams and Moodle in August 2020. PAAET urged all their academics faculty, staff, and students to enroll in training courses that was run by PAAET. This study stems from our worries as instructors and researchers about the ability of our student- teachers to be in a good shape for E-learning. One of the main findings the study revealed is that CBE students carry a high level of readiness to E- learning. The researchers believe that the high level of readiness of our students towards Elearning comes from the large campaign that PAAET launched for all their colleges and institutes.

The training campaign played a role in motivating the students and in making them feel ready to utilize distant E-learning. This is reasonable since their experience through many training sessions that they got online helped them effectively in two main ways. First, in removing their fear and anxiety towards using E-learning platforms such as Microsoft Teams and Moodle. Bozkurt et al. (2020) pinpointed an important aspect of education, especially with distance education, which is the pedagogy of care, affection, and empathy. Bozkurt et al. (2020) emphasized the importance of compassion during COVID-19 and beyond. For them, it is a concept that has always been needed and will continue to be required even after COVID-19. Zembylas (2013) went further to indicate that the trauma which is caused by COVID-19 requires educators and administrators to utilize intentional practices which depend on care, compassion, and empathy. We believe that the training students got during many sessions, day and night, from different familiar instructors in CBE helped in providing the students with that type of care and empathy that played a role in accepting distant E-learning and eventually using it comfortably.

Second, the training provides them with knowledge and skills they need for using those platforms. Training is a very important step to start with before launching any distant E-learning project. With having the actual knowledge and skills they need; the students would feel ready and capable of entering the new experience. In other words, ignorance is the parent of fear. Therefore, if we do not want them to feel pressured with E-learning or experience the fear of failure in using E-learning, we need to educate them on how to use E learning platforms first. Thus, we believe that the training provides them with a good chance to experience the feeling of confidence, compassion, and relief. An evidence of this is found in our data in which students seem uncertain about the effectiveness of E-learning over the traditional method $(\mathrm{M}=2.77)$. This is common, especially when it comes to novel use of technology in countries such as Kuwait where technology was never integrated appropriately before the COVID-19 pandemic. Although students may feel ready as they are users of technology, they are unaware about the use of technology in teaching and learning contexts. This may explain their need for training as shown in their responses $(\mathrm{M}=3.89)$.

All the previous background leads us to conclude that training is the most essential phase. This is because training contributed positively in improving students' E-learning skills, provided them with the experience that helped in reducing fear and gaining confidence that will guide them to start their E-learning journey. Thus, we can recommend modifying Akaslan and Law' (2011) model making training the first phase, readiness the second phase, and acceptance the third phase. The second recommendation is that this study needs to be followed by another that investigates students' reflections after the actual experience of E-learning with their instructors. This should happen after completion of a full semester online. Such follow-up studies can help in increasing students' productivity in autonomous learning and enhance the quality of education beyond the COVID-19 pandemic. This is because such study can pinpoint the specific issues and problems that are faced by the students which eventually may be solved by finding the right solutions.

\section{References}

Akaslan D., Law E.L.C. (2011) Measuring Student E-Learning Readiness: A Case about the Subject of Electricity in Higher Education Institutions in Turkey. In: Leung H., Popescu E., Cao Y., Lau R.W.H., Nejdl W. (eds) Advances in Web-Based Learning - ICWL 2011. ICWL 2011. Lecture Notes in Computer Science, vol 7048. Springer, Berlin, Heidelberg. https://doi.org/10.1007/978-3-642-25813-8 22

Al darwish, S., \& Akbar, R. (2013). EFL reading motivations: Evidence from Kuwait. Journal of Education and Practice, 4 (28), 203-211.

Aldhafeeri, F. \& Khan, B. (2016). Teachers' and Students' Views on E-learning Readiness in Kuwait's Secondary Public Schools. Journal of Educational Technology Systems 45(2), 202-235.

Al-Juda, M. (2017). Distance learning students' Evaluation of E-learning System in University of Tabuk, Saudi Arabia. Journal of Education and Learning, 6 (4), 324-335.

Apparvoo, P., Soyjaudah, K., \& Armoogum, V. (2015). Assessing Young Learners' Readiness to Embrace ICT for Pedagogical Gain. The International Journal of E-Learning and Educational Technologies in the Digital Media (IJEETDM), 1(3), 154-166.

Arbaugh, J., \& Duray, R. (2002). Technological and Structure Characteristics, Students Learning and 
Satisfaction with Web-based Courses: An Exploratory Study of Two On-line MBA Programs. Management Learning, 33(3), 331-348.

Aydin, C. \& Tasci, D. (2005). Measuring readiness for e-learning: reflections from an emerging country. Educational Technology \& Society 8(4), 244-257.

Banathy, B. (1991). Systems designs of education: A journey to create the future. Englewood Cliffs, NJ: Educational Technology Publications.

Banathy, B. (1992). A system view of education: Concepts and principles for effective practice. Englewood Cliffs, NJ: Educational Technology Publications.

Bean, M. (2003). Are you ready for e-learning? Assessing e-learning readiness: Tips and tricks of the trade. MediaPro News. Retrieved from http://www.mediapro.com/html/resources/news1-vol5-01.htm

Bozkurt, A. Jung, I., Xiao, J. Vladimirsch, V., Schuwer, R., \& Egorov, G.(2020). A global outlook to the interruption of education due to COVID-19 Pandemic: Navigating in a time of uncertainty and crisis. Asian Journal of Distance learning, 15(1), 1-126.

Chapnick, S. (2000). Needs assessment for e-learning. Alexandria VA: ASTD.

Clark, R. C., \& Mayer, R. E. (2003). E-learning and the science of instruction: Proven guidelines for customers and designers of multimedia learning. San Francisco, CA: Pfeiffer.

Cooper, H. (2009) Research Synthesis and Meta-analysis: A Step by Step Approach, 4th edition. Thousand Oaks, CA: Sage. https://doi.org/10.4135/9781483348858.n11

Demir, Ö. \& Yurdugül, H. (2015). The Exploration of Models Regarding E-Learning Readiness: Reference Model Suggestions. International Journal of Progressive Education, 11 (1), 173-194.

De Villiers, M. (2005). E-Learning artefacts: are they based on learning theory? Alternation 12 (1b), 345-371.

Ford, J., Ford, L., \& D'Amelio, A. (2008). Resistance to Change: The Rest of The Story. Academy of Management Review, 33(2), 362-377.

Hung, M.-L., Chou, C., Chen, C., \& Own, Z. (2010). Learner readiness for online learning: Scale development and student perceptions. Computers \& Education, 55(3), 1080-1090.

Kaur, K., \& Abas, Z. (2004, November-December). An assessment of e-learning readiness at the Open University Malaysia. Paper Presented at the International Conference on Computers in Education (ICCE2004), Melbourne, Australia.

Kentnor, H. (2015). Distance Education and the Evolution of Online Learning in Distance Education and the Evolution of Online Learning in the United States United States. Curriculum and Teaching Dialogue, 17 (1, 2), 22-34.

Khan, B. (2005). E-learning quick checklist. Hershey, PA: Information Science.

Kituyi, G., \& Tusubira, I. (2013). A framework For the Integration of E-learning in Higher Education Institutions in Developing Countries. International Journal of Education and Development using Information and Communication Technology, 9(2), 19.

Lopes, C. (2007). Evaluating E-learning Readiness in A health Sciences Higher Education Institution. Paper presented at the Proceedings of IADIS International Conference of E-learning, Porto.

Mercado, C. A. (2008). Readiness Assessment Tool for an eLearning environment implementation. Paper presented at the Fifth International Conference on eLearning for Knowledge-Based Society, Bangkok.

Moftakhari, M. (2013). Evaluating e-learning readiness of faculty of letters of Hacettepe (Unpublished Master's Dissertation). Hacettepe University, Ankara, Turkey.

Mosa, A., Naz'ri bin Mahrin, M., \& Ibrrahim, R. (2016). Technological aspects of E-learning readiness in higher education: A review of the literature. Computer and Information Science, 9(1), 113-127.

Ncube, S., Dube, L. \& Ngulube, P. (2014). E-learning Readiness among academic staff in the department of Information and Science at the University of South Africa. Mediterranean Journal of Social Sciences, 5 (16), 357-366.

Neubauer, M. \& Lobel, M. (2003). The learning by doing e-classroom, Journal of the USDLA,17 (2), 5-17.

Oliver, R. (2001). Assuring the quality of online learning in Australian higher education. Proceedings of 2000 Moving Online Conference (222-231). Gold Coast, QLD. Norsearch Reprographics.

Ouma, G., Awuor, F., \& Kyambo, B. (2013). E-learning readiness in public secondary schools in Kenya. European Journal of Open-Distance and e-Learning, 16 (2), 56-73.

Payton, D. M. (2015). EffectiveJ teaching in higher education for the 21st century adult learner (Unpublished Doctoral Dissertation). Minneapolis, MN: Walden University.

Rasouli, A, Rahbania, Z , \& Attaran, M. (2016). Students' Readiness for E-learning Application in Higher Education. Malaysian Online Journal of Educational Technology, 4(3). 51-64.

Soydal, İ., Alır, G., \& Ünal, Y. (2011). Are Turkish Universities Ready for E-learning: A Case of Hacettepe University Faculty of Letters. Information Services \& Use 31, 281-291.

Tarus, J., Gichoya, D., \& Muumbo, A. (2015). Challenges of Implementing E-learning in Kenya: A case of Kenyan Public Universities. The International Review of Research in Open and Distributed Learning, 16 
(1), 120-141.

Tubaishat, A., \& Lansari, A. (2011). Are students ready to adopt e-learning? A preliminary e-readiness study of a university in the Gulf region. International Journal of Information and Communication Technology Research, 5(1), 210-215.

Ünal, Y., Alır, G., \& Soydal, İ. (2014) Students Readiness for E-Learning: An Assessment on Hacettepe University Department of Information Management. In: Gathegi J.N., Tonta Y., Kurbanoğlu S., Al U., Taşkın Z. (eds) Challenges of Information Management Beyond the Cloud. IMCW. (2013). Communications in Computer and Information Science, vol 423. Springer, Berlin, Heidelberg

Watkins, R., Leigh, D., \& Triner, D. (2004). Assessing readiness for e-learning. Performance Improvement Quarterly, 17(4), 66-79.

WHO. (2020). Coronavirus disease (COVID-19) Pandemic. World Health Organization. https://www.who.int/emergencies/diseases/novel-coronavirus-2019

Wojciechowski, A., \& Palmer, L. B. (2005). Individual student characteristics: Can anyone be predictors of success in online classes? Online Journal of Distance Learning Administration, 8(2), 1-20.

Xu, D., \& Jaggars, S. (2013). Adaptability to online learning: Differences across types of students and academic subject areas. Retrieved from https://ccrc.tc.columbia.edu/media/k2/attachments/adaptability-to-onlinelearning.pdf

Yuyun, I. (2013). E-language learning program: problems and challenges. Paper presented at the TEFLIN International conference, Jakarta, Indonesia. Retrieved from file://C:/Users/Anam\%20AlFadley/Downloads/E-LanguageLearningProgramProblemsandChallengesbyIgnasiaYuyun\%20(1).pdf

Zabadi, A, \& Al-Alawi, A. (2016). University Students' attitudes towards E-learning: University of Business \& Technology (UBT)-Saudi Arabia-Jeddah: A Case Study. International Journal of Business and Management 11 (6), 286-295.

Zembylas, M. (2013). Critical pedagogy and emotion: Working through 'troubled knowledge' in posttraumatic contexts. Critical Studies in Education, 54(2), 176-189. 